\title{
"All Pink and Clean and Full of Wonder?" Gendering "Joni Mitchell," 1966-74
}

\section{Stuart Henderson}

\author{
Just before our love got lost you said: \\ "I am as constant as a northern star." \\ And I said: "Constantly in the darkness - \\ Where's that at? If you want me I'll be in the bar." \\ - "A Case of You," 1971
}

Joni Mitchell has always been difficult to categorize. A folksinger, a poet, a wife, a Canadian, a mother, a party girl, a rock star, a hermit, a jazz singer, a hippie, a painter: any or all of these descriptions could apply at any given time. Moreover, her musicianship, at once reminiscent of jazz, folk, blues, rock ' $n$ ' roll, even torch songs, has never lent itself to easy categorization. Through each successive stage of her career, her songwriting has grown ever more sincere and ever less predictable; she has, at every turn, re-figured her public persona, belied expectations, confounded those fans and critics who thought they knew who she was. And it has always been precisely here, between observers' expectations and her performance, that we find contested terrain.

At stake in the late 1960 s and early 1970 s was the central concern for both the artist and her audience that "Joni Mitchell" was a stable identity which could be categorized, recognized, and understood. What came across as instability to her fans and observers was born of Mitchell's view that the honest reflection of growth and transformation is the basic necessity of artistic expression. As she explained in 1979:

You have two options. You can stay the same and protect the formula that gave you your initial success. They're going to crucify you for staying the same. If you change, they're going to crucify you for changing. But staying the same is boring. And change is interesting. So ... I'd rather be crucified for changing. ${ }^{1}$

What has been embraced by many spectators for decades as the essential core "Joni Mitchell" was gleaned from her early artistic development, from what was little more than the expression of those few moments in her life. In retrospect, this period appears as a particular performance of "Joni Mitchell" richly expressive and honest to the particularities of the moment, but ultimately revealing little about the future or past.

Mitchell rarely anticipates her own artistic development — rather, she

83

(C) Left History

10.2 (Fall 2005) 
embodies the moment of expression, channels it, performs it. She is, as a result, a difficult artist; she is challenging, surprising, unpredictable. Fiercely independent, she has never relinquished artistic control on any of her records. Her "sound," we could say, is her own. ${ }^{2}$ She seems to invite listeners into her world, perhaps even her soul. Her confessional poetry achieves a degree of intimacy so intense that many critics and fans have made the peculiar claim to actually know her through her music. The immediacy of Mitchell's work is unparalleled, and is perhaps her greatest achievement. Yet the tension between this immediacy and the retrospective expectations of her observers tends to underscore whatever narrative one might construct out of her public life.

This article will discuss the first stages of Joni Mitchell's career (19661974), comprising her apparent move from folk music to rock ' $n$ ' roll and beyond. Although mimicking biography, it aims to establish and explore some of the peculiar ways gender has figured into constructions of her identity. Her often contradictory stances on (and performances of) gender are worth considering in detail as they, at every turn, reflect her responses to the cruel realities faced by a trailblazing female artist in a male-dominated, market-driven music industry. From her early days as a folksinger in Toronto's Yorkville and elsewhere, through her failed marriage, into her development as a recording artist and eventual star, to her subsequent embrace of jazz and rock ' $n$ ' roll (or, rather, her turn away from the folk mantle), critics and observers alike have struggled to make sense of Mitchell's gender performances. By turns described as girlish, feminine, womanish, mannish, ethereal, and masculine, Mitchell has eluded any easy classification. She has, consistently and impressively, remained enigmatic to her observers.

Mitchell has always bristled at the inclination of critics and music historians to treat her as a female musician - her reticence flowing from a deeply held belief that her music (and, by extension, all great art) should be genderless. She is no female singer-songwriter: there is likely no more expedient way to terminate an interview than to suggest this to her. ${ }^{3}$ She refuses feminism and has described homosexuality as something to which she can relate, but which she does not believe in. She also backs off from being seen as a white artist - she has claimed that the greatest compliment she ever received came from a blind, black pianist who told her that she makes "genderless, raceless music." This quest for universality in her art, however, can only be discussed with regard to the great difficulty others have had in allowing her that claim.

\section{Joni Mitchell, Women, and the Music Industry, 1966-74}

The study of women in rock music has received some sustained academic attention in the past decade, but Mitchell has not been at the heart or even on the periphery of much of this. Books such as Gillian Gaar's She's a Rebel and Ellen 
Schwartz's Born a Woman which focus on the particular problems encountered by women in the recording industry are largely underdeveloped attempts to connect the marginalization of women musicians to a more general marginalization of women in society. 5 Wy, such studies demand, has rock ' $n$ ' roll always been seen as a male domain? But the general preoccupation in most works on women in the industry tends to be with women who clearly appropriate these "male," rocker roles - Patti Smith and Janis Joplin are two of the most common subjects. ${ }^{6}$ The basic concern has been with women who are most unambiguously read as bona fide rockers but the apparent clarity of the formula -- woman appropriates male role through rock ' $n$ ' roll - cannot be so easily applied to Joni Mitchell.

There exists no thorough academic study of Joni Mitchell's work. Moreover, there are only two proper takes on her biography, and neither of these is authorized. ${ }^{7}$ In the better of the two (2002's Shadows and Light), BBC radio producer Karen O'Brien accounts for this scarcity of resources by suggesting that Mitchell's "womanness" is central to her under-appreciation. While O'Brien's book is exhaustive and at times fascinating, it suffers from a conspicuous lack of critical or theoretical treatment of the material. The complexity of Mitchell's position as a white woman in a male dominated industry is considered at every turn, but there is a persistent want of analysis of her performances of this position.

However, Mitchell has rarely escaped the music essayist's gaze, and as a result there is a great deal of journalistic material available on her work. Notable writers such as Alice Echols, Douglas Fetherling, Marco Adria, among many others, have examined different aspects of Mitchell's artistry and performances. ${ }^{8}$ By far the best of these is Echols' brilliant (if frustratingly brief) essay, written in 1994 but republished last year under the odd title, "The Soul of a Martian." Combining excerpts from an interview she conducted herself with her own insightful analysis of Mitchell's performances, Echols' essay discusses, but never really explores, many of the key themes on which this paper will elaborate. In some ways we share a basic premise that Mitchell was and continues to be misunderstood, undervalued, and unexplored because she has always presented herself in contradictory, challenging, and confusing ways. Her expected identity, apparently stable as "Joni Mitchell," has projected so many meanings as to have become too complicated to be immediately predictable. ${ }^{10}$

\section{Theorizing "Joni Mitchell": Signatures, Performance, Gender}

In the second half of the $1960 \mathrm{~s}$, categories of musical genres were expanded substantially both to accommodate the expanding field of popular music and to enable record companies to maximize sales potential by marketing their artists 
to particular audiences. Categories such as folk, rock ' $n$ ' roll, blues, and eventually folk-rock, soul, pop, and psychedelic rock were broken down along gender, race, national, and class lines, and employed as a means to remove any doubt as to the coherence of the product. This is how we can begin to speak today of a proto-funk, folk-tinged, afro-Cuban, grrl-rock singer/songwriter. ${ }^{11}$ In what has come to seem an inevitable reality of the music business, the power exercised over artists by the industry often results in bitter struggles over artistic freedom - for what if one feels limited by such categories? ${ }^{12}$ For a challenging, groundbreaking, and genre-defying artist such as Joni Mitchell, these categories were perceived to operate as cages, hemming her in, denying her inventiveness. In this way, her persistence at operating outside of the confines of expected musical (and gender) categories can be regarded as a certain counter-hegemonic force within the industry. Her dissatisfaction with the insistence that she fit some expected mould - whether as a white woman, a folk singer, a rock star - inspired her to respond with breathless vivacity and ingenuity. The resistance she met only further entrenched her desire for more space, and more power.

To interrogate the stability of gender, sexuality, and race in the internal and external constructions of "Joni Mitchell," this article refuses the totalising categories that separate behaviours as gender-, hetero-, class-, or race-specific and will be thus freed from the constraints of any simple understanding of identity. As Judith Butler has famously argued, "there is no gender identity behind the expressions of gender ... identity is performatively constituted by the very 'expressions' that are said to be its results." 13 In this view, gender is not a stable, foundational feature of one's identity, but rather an expected manner in which to operate. Following Butler, I tend toward a wide view of the disjuncture between identity and expression. This article considers gender (as it does other apparently immutable aspects of identity) to be a role that is performed, and thus very much reflective of shifting permutations in hegemonic ideology. The commonsense performances of gender correspond to hegemonic ideologies which suggests or, in some cases, decree the manner in which to act within the boundaries of normalcy. ${ }^{14}$ Examining the ways in which Joni Mitchell performed (and/or appeared to perform) various counter-hegemonic gender and other roles will allow us to recognize and more fully investigate the mutability of performance, action, and identity. ${ }^{15}$

But, as with every performance, interpretation is at least as important as articulation. We must not only consider Mitchell's particular performances of gender and identity, but also the ways in which they were received, understood, and interpreted by others. A useful means of getting at this divide between the public and private meanings of identity performance is to consider the concept of signature. For Joni Mitchell, her signature (which often quite literally appears on her album sleeves) may signify authorship, ownership, and control. 
However, although it is a means of asserting individual identity, it is also the name made tangible (or, at least visible), and thus it passes into the public realm where it can be reproduced, scrutinized, exalted. As Jacques Derrida has argued, it is through the very iterability of the signature that it tends to lose its essential function as an expression of individual identity. ${ }^{16}$ Not only must I repeatedly sign my name to assert my authorship over things, but others may now see my signature and recognize this as my work. My signature, and thus, my name, has become a part of the public domain, prone to subjective interpretation and external manipulation. The signature is no longer under my exclusive control, but rather is open to the various interpretations of all those who see it, recognize it, and glean some meaning from it. Thus, as Stephen Scobie has argued, "the proper name lives on as that which exceeds individual identity. A public name like "Bob Dylan" is no longer within the control of the man who happens to bear it; it has gone beyond him.... Once the name is signed, it is on its own." In the case of Joni Mitchell (as with Dylan, another artist whose efforts to diversify his artistry and expected image have elicited cries of frustration from observers), the paradox of the signature, as both an expression of individuality and a figurative prison from which the artist must somehow repeatedly escape, is a recurring theme in her work.

\section{Biography I: Becoming Joan, Becoming Joni, 1943-1967}

"Joni Mitchell" was born Roberta Joan Anderson in Fort Macleod, Alberta, on 7 November 1943. She would later joke of her Christian names that her parents had expected a boy (Robert John) and had to make do with what they got. ${ }^{18}$ The Anderson family moved around a fair bit in the immediate post-War years, finally landing in Saskatoon, Saskatchewan in 1954. Along the way, their daughter had spent the better part of two years struggling through piano lessons (the only formal musical training she would ever receive) and enduring the loneliness which comes along with frequent upheaval. This loneliness was never felt so keenly as when, at age 9 , she contracted polio. She recalls the day she fell ill:

I dressed myself that morning in pegged grey slacks, a red and white gingham blouse with a sailor collar, and a blue sweater. I looked in the mirror, and I don't know what I saw — dark circles or a slight swelling in my face - but I said to myself, 'You look like a woman today.'[...] Next day, I woke and my Mum said, 'Get up! Come!' I said, 'I can't.' She didn't believe me and yanked me out of bed, and I collapsed. ${ }^{19}$

Laid up in a hospital bed for months, the virus twisting her young spine, Joan was cut off from her childhood. From the beginning, at least on some level, Mitchell related her womanness to an illness. ${ }^{20}$ 
She might have been overzealous to date her ascension to adulthood from this event, but we may treat it as the beginning of a new stage in her life. "Polio probably did me good," she has remarked. "Otherwise I would have been an athlete ... I believe convalescence in bed develops a strong inner life in a young child. I think it solidified me as an independent thinker. Nietzsche was a convalescent." ${ }^{21}$ She spent both Christmas and her tenth birthday in the polio ward, surrounded by her thoughts, cut off from her peers, struggling with pain and isolation.

Once recovered, Joan Anderson matured into a lover of art, an insatiable dancer, and a blissful troublemaker. She tended to find the ersatz homogeneity of white, suburban Saskatoon too uptight for her liking - she would steal away at night to the centre of town to party with Indian and Ukrainian teenagers. ("They were better dancers," she claimed. "Less inhibited.") ${ }^{22}$ Her school report cards reflected her disaffected demeanour; "Joan does not relate well" was a repeated observation. ${ }^{23}$

She adopted the second name "Joni" on a whim. Ever the poet, the painter, the observer of detail and design, she loved the way her art teacher's name, Henry Bonli, looked when he signed it across one of his paintings. The hanging " $\mathrm{i}$ " seemed indefinite and attractive. ${ }^{24}$ The name Joni became the artist's pseudonym - while her friends would continue to know her as Joan, she would henceforth refer to herself as "Joni" when crediting her work. Like another young artist-in-training, Robert Zimmerman, later Bob Dylan, adopting a second name seemed appropriate, even necessary. ${ }^{2 s}$ There would be two Joans: one "the flesh" (Joan), the other "the name" (Joni). The distinction between the two signatures will always be hazy - for it is always difficult, if not impossible to separate the artist from her art.

Always inward-looking, Joni the artist-in-waiting turned to painting to satisfy her desire to express herself. In order to attend Alberta College of Art in Calgary, she began to work as a model in local dress shops. "You had to be a size eight, but the pay was pretty good," she remembers. ${ }^{26}$ Eventually, she took a job at a local coffee house, the Louis Riel, and it was here that she became enamoured of the burgeoning folk music scene. She rushed out, bought a baritone ukulele, and began to play at open-mic nights, but failed to impress. One former owner of the Louis Riel famously recalls being struck by Joni's "terrible voice."27 However, her voice, along with her musicianship, would improve immeasurably. She finally bought a guitar and taught herself to play, but found herself unable to master the left hand technique of "Cotten Picking" which was so ubiquitous amongst early-60s folk musicians. ${ }^{28}$ It was the lingering effects of polio which, by limiting her dexterity, caused Joni to adopt open tunings on her guitar. Not only had the childhood disease turned her into an "independent thinker" but it had also forced her to develop an original guitar technique. ${ }^{29}$

While at art school, Joni became pregnant. Then 20 years old, and with 
merely wavering intentions of marrying the father, she hid the pregnancy from her friends and family, fearing that "to be pregnant and unmarried in 1964 was like you killed someone." ${ }^{\prime 30}$ The pair left Calgary together in the early summer and headed to Toronto. Arriving without any money, they lived for a time in a flophouse in Toronto's Annex district, just west of Yorkville, home to the city's fledgling folk music scene. Before long, her partner was gone, and she was left to face both pregnancy and poverty alone. She began to perform on various stages, and supported by welfare cheques she was able to move into an apartment with a friend and folksinger Vicky Taylor. ${ }^{31}$ She gave birth to a baby girl in February 1965 whom she named Kelly Dale Anderson. Faced with the apparent irreconcilables of poverty and motherhood, she gave up the child to foster parents and eventual adoption, a decision which would haunt her for decades to come. ${ }^{32}$ She would crystallize her pain in a stunning song, "Little Green," written in 1967 and recorded in 1971:

Child with a child pretending,

Weary of lies you are sending home

So you sign all the papers in the family name

You're sad and you're sorry but you're not ashamed;

Little Green, have a happy ending. ${ }^{33}$

In June of that year, she met an American folksinger from Detroit named Chuck Mitchell and the two quickly fell in love. After a whirlwind 36-hour courtship, he asked her to marry him. They moved down to Detroit and began to tour as husband and wife, sharing the stage and performing as a unit. ${ }^{34}$ An interview with the Detroit News in early 1966 demonstrates the way in which her new role as "wife" in the duo was perceived by some observers:

Chuck said, "Joni and I have developed our act. We are not just folk singers now. We do comedy, sing some ragtime and do folk-rock. We're ready for the big clubs now." Joni nodded her approval, as any dutiful wife would do. ${ }^{35}$

This was not going to work. Both the musical and the romantic partnership proved fractious - Joni's desire for independence (both artistic and otherwise) could never be satisfied under the terms of this arrangement. "I felt that I couldn't grow with Chuck, that we would never grow together, that I had to separate myself from the duo," she recalled in a 1973 interview, "I had to become an individual in order to grow. ${ }^{" 36}$ And so, Joan Anderson began to practice her new signature: the solo artist, the singer-songwriter, Joni Mitchell.

\section{Women, Politics, and the American Music Industry in the late 1960s}

The American music industry of the 1960 s largely reflected the political realities of the gender, class, and racial dominance of affluent white men. Ever since the mid-1950s and the emergence of rock ' $n$ ' roll and folk music as viable com- 
mercial genres, the standard for mainstream acceptance and respect had been developed around the image of one or two white men backed by a group of more white men. ${ }^{37}$ Record companies tended to view their female and nonwhite artists as commercially insignificant while strenuously promoting their white male artists. This marketing strategy resulted in a marginalization and "othering" of certain groups, and their relegation to categories outside of the mainstream. However, as Gillian Gaar has pointed out, at the same time as this ideal of the white male pop star was being developed and entrenched, subaltern musicians, especially women and blacks, maintained a persistent challenge to this hegemonic image:

Women performers have often been caught in a double bind.

Female artists were (and are) frequently not seen as having the commercial potential of a male artist, and so were not given the chance to demonstrate that they could indeed sell records on their own merits.... When given the opportunity, women performers have proven again and again that they can sell records, but doubts about the ability of women artists to make records that people will actually want to buy remain $\left[\right.$ sic.$^{38}$

As a result, the history of women in the American music industry of the 1960s is, in many ways, the history of the few iconic female artists and performers in a sea of countless men. Women in the music industry were the exception, not the rule - it was simply expected that a pop star be a white man.

However, as Gaar points out, the exception constituted by women in the industry frequently amounted to a commercially significant force..$^{39}$ From the great successes of "girl groups" such as the Chantels in the 1950s and the Supremes in the 1960s to the primacy of such folk singers as Joan Baez and Judy Collins in the first half of the 1960s, women musicians were clearly capable of consistently performing commercially viable material. ${ }^{40}$ As Echols has noted, "by the early sixties women girl groups had established a beachhead for women in rock ' $n$ ' roll. But if their songs were widely popular, the singers themselves, with the exception of Diana Ross, remained anonymous - nameless and faceless to their listeners because record companies treated them like so many interchangeable cogs in a musical assembly line." repeated successes for women seemed categorically determined - for black women, the girl group or, increasingly, the solo singer backed by an all-male band as in the case of Motown or Stax, became the expected category. ${ }^{42}$ For white women, it was either folk music or saccharine pop (the category which most resembled the "musical assembly line" of Echols" view). However, expectations for the commercial viability of folk music began to lose ground following folk icon Bob Dylan's electric turn in 1964-5 and the ensuing general move by white male popular music toward folk-rock as the next great terri- 
tory to populate and explore..$^{43}$

The industry's focus widened considerably in these years and, as Echols has pointed out, this allowed for the grudging acceptance of many more diverse roles for women as performers and musicians. ${ }^{44}$ White women, especially those emerging from the heady San Francisco and Los Angeles scenes in 1966-7 such as Janis Joplin, Grace Slick, and Cass Elliot, began to challenge the industry's expectations of women as rock ' $n$ ' roll musicians, artists, and sexual beings. When Joni Mitchell re-entered the music world in 1967, rising from her failed marriage armed with a re-focused sense of her own individuality, and a new signature, she was not immediately caught into the double-bind Gaar points out above, since she was riding the cusp of a new understanding of the possibilities for women in public. ${ }^{45}$

Certainly, the story of popular music in the 1960s is intimately bound up with the story of the countercultural movements, such as those associated with the hippies (one hesitates to refer to this as a "movement"), the New Left, and civil rights organizations such as the Student Non-Violent Co-Ordinating Committee, Women's Liberation, and the National Organization for Women. ${ }^{46}$ Although Mitchell has gone rather out of her way to eschew any link between her gender performances and feminism, it is very difficult to treat her brand of "gender trouble" (or challenges to expected gender roles and behaviours) as an unrelated phenomenon. ${ }^{47}$ Put simply, debates surrounding the meanings, roles, and performances of woman and womanness became ever more heated and fractious by the late $1960 \mathrm{~s}$, as liberal feminism, largely represented by Betty Friedan and the National Organization for Women, was engaged by an emerging Woman's Liberation Movement. If the feminist program of the former entailed the integration of women into the mainstream, "radical feminism embodied a rejection of the mainstream itself." inists defined the problem as women's exclusion from the public sphere, radical feminists focused on the sexual politics of personal life." ${ }^{\prime 49}$ By 1968, the Women's Liberation Movement was associated with the immensely influential slogan "The Personal is Political," further disseminating its view that "the individual is the point of origin for all subsequent political action or social change." "so By the late 1960s, radical feminism began to challenge the very ideas of "man" and "woman," seeking to re-define and refigure the power relation between the categories. As debates over the meanings of the public performance of gender played out through mounting protests, marches, and in the pages of influential articles and books, women in the late 1960s who may have felt no affinity with the Women's Movement began to benefit from this persistent challenge to the liberal order.

Spilling into the first half of the 1970 s, there was a generalized expanding awareness of the possibilities for women in the public sphere, and it is in this context that Mitchell's story must be placed. However, it is dangerous to infer 
too much from this "new understanding." As we shall see, Mitchell's rise to stardom may have been unthinkable in the absence of these developments, but she was still beset on all sides by an industry and buying public whose expectations for a female singer-songwriter proved difficult to circumvent.

\section{Biography II: The Female Songwriter's Male Signature, 1968-1970}

Moving to New York, Mitchell began to exercise her desire for individuality she started to write feverishly. She would reap the rewards of her efforts almost immediately. Performing her new material in front of other aspiring folk musicians introduced her songs to a thin, but influential audience. Soon, other more established artists such as Judy Collins and Tom Rush were recording some of her earliest compositions. ${ }^{51}$ As her notoriety grew, she made her way out to California with new lover (and ex-Byrd) David Crosby, intent on recording her first album. The result, Song to a Seagull (1968), showcased her fine songwriting, soaring soprano, and what could be described as a remarkable lack of desire to court the pop charts - her three most famous songs ("Urge for Going," "Both Sides Now," and "The Circle Game," all made popular by other people) were conspicuously absent from the record. Moreover, there was no apparent attempt to crack the pop charts - the spare, minimalist production emphasised Mitchell's innovative guitar tunings and daring vocal arrangements and seemed to actively avoid any formulaic approach to the songs. As Mitchell explained later, "David Crosby pretended to be a producer on the first record but all he did was stick me in front of a microphone. It was to keep them from turning me into a folk rocker [and] laminating things artificially." 52

Her next two albums, Clouds (1969) and Ladies of the Canyon (1970) reflected life amongst the artists, stars, and hippies in Laurel Canyon, California. The songs tended toward artful meditations on love and loss, vanity and exploration. If there was ever a sustained, cohesive period in Mitchell's career, it is this. ${ }^{53}$ In these first few records, Mitchell was grappling with her sudden fame, the loss of her child, her first husband, and a succession of suitors and lovers with whom she struggled to reconcile her need for companionship with her fear of enclosure. There is much joy, but also a great deal of sadness colouring the poetry. Stylistically, the music is vaguely "folky," but only appears so because it is played on acoustic instruments - not much of this material, with its stirring rhythms, unexpected melodies, progressions and phrasing, sounds like the Childe Ballads. ${ }^{54}$

Throughout this period, critics and observers seemed unable to decide what role to ascribe to Mitchell. As Holly Kruse has pointed out, "traditionally, popular male-generated criticism has tended to view women from a few different angles, all of which seem to assume at some level that women in rock and roll are anomalies, 'others', and therefore can be talked about in ways that would be 
unthinkable for speaking of male artists. " ${ }^{55}$ In the critical work surrounding her first three records, Mitchell was largely described as an innocent; she was fragile, vulnerable, and girlish. But with 1971's Blue, reviewers began to speak of her maturation into an adult musician, and into a woman. For critics, what was easily explained in the context of an innocent girl (naïveté, prettiness, idealism, romance) became more problematic now that Mitchell had "matured." She was now seen as challenging, dark, insightful - her sadness could no longer be disregarded as mere growing pains. And yet, once critics were forced to take her more seriously, her womanness became conflated with an apparent maleness. The unsteady middle ground between girl and woman was rocked by Mitchell's trespasses through her songwriting into male artistic territory. ${ }^{56}$ Moreover, it was undeniable that she was never merely a pretender to the male role - with every record, Mitchell was demonstrating her idiosyncratic vision of the art of composition. $^{57}$

Mitchell was compared almost entirely to male songwriters, a gesture which reminds us that she was a pioneer as a female singer-songwriter in the music industry. Of the three towering female figures in the 1960s folksinger genre, she was the only one who wrote her own material. In most early accounts, comparisons with Joan Baez and Judy Collins were ubiquitous, but the sense was that if these two mavens were women, then she was the childish aspirant. According to a Philadelphia Evening Bulletin article in 1968, Mitchell was seen as "the most exciting girl singer since Judy Collins, since Joan Baez." 58 Happy Traum, in a telling attempt to place Mitchell in the gendered context of these two women, wrote in 1969 that "where Joan Baez is the embattled but still charming Joan of Arc of the non-violence crusade, and where Judy Collins is the regal long-time lady-in-waiting of the folk-pop world, Joni Mitchell is a fresh, incredibly beautiful innocent/experienced girl/woman." 59 Traum can explain the first two artists using the definite article (Baez is the Joan of Arc, Collins is the lady-in-waiting), but he is less sure about Mitchell. He has trouble reducing her to any definite role, apart from "beautiful"; she is rather presented through dualities. Mitchell is, for Traum, neither fully a girl nor entirely a woman, yet somehow acutely both.

As a female solo artist in an industry which often exalts physical attributes over artistry, Mitchell was confined to a frustratingly narrow field of critical approval. She was routinely praised for her corporeal beauty, her "high cheek bones," ${ }^{60}$ "striking" features, ${ }^{61}$ her "tall, willowy" figure, ${ }^{62}$ and her blonde hair, "long as uncut wheat." ${ }^{63}$ And this emphasis on her aesthetic appeal tended to mirror the critical response to her artistic endeavors. Image was taken to dictate both substance and capability.

The gendered space demarcated by the description "girl," understood through its implications of youthfulness, innocence, and levity, served as the territory in which Mitchell's early signature was situated. Moreover, since 
some of her early compositions were infused with a kind of fairy tale imagery, many critics were quick to describe her as childish, even childlike, confusing the writing with the writer. As John MacFarlane put it in 1968, "sometimes it's the voice of a little girl, all pink and clean and full of wonder. The voice of innocence. And sometimes it's the strong and slightly melancholy voice of a woman, a voice that's hurting a little. It's fascinating - the voice of the woman who has grown up and knocked around without losing the little girl inside her." ${ }^{\circ 4}$ At every turn, Mitchell was described as girlish, childish, but always with this sense that the label did not quite fit, that she was somehow duplicitous in her performance. For not only was her role as girl confused by her apparent womanness (she was, after all, in her mid-20s), it was further complicated by her persistence in borrowing from the male territory of songwriting.

In the recent view of music journalist Bill Flanagan, the appeal of Mitchell's image stemmed from a surprising conflation of girlish beauty with masculine prowess:

[Mitchell] took this really potent, popular image that had been building for 7 or 8 years anyway, the California Girl, the Beach Boys girl, the beautiful golden girl with the long blonde hair parted in the middle ... and Joni not only was "the girl," but she was also the "Bob Dylan," the "Paul Simon," the "Lennon and McCartney" writing it, you know? I mean, she was the whole package. She was the subject, and she was the painter....65

Yet while this "whole package" of male talent and female beauty may appear clear to Flanagan in retrospect, it was rarely understood so plainly in contemporary reflection. Rather, critics were left to wrestle with an artist who simply did not fit.

\section{Making Joni Mitchell “Fit,” 1969-1970}

Once she had arrived in California in the late 1960s and begun to enjoy some widespread fame, Mitchell's lyrics shifted toward more confessional poetry. ${ }^{66}$ Out of this, one of the more troubling aspects of Mitchell's public persona for many observers became her sex life. She had more than a few partners in the years following her breakup with Chuck, and rarely did she receive any press that neglected to include information on these romantic entanglements. This preoccupation with her love and sex life began to snowball alongside her growing fame, while a series of famous lovers contributed to the public fascination.

Mitchell's role as sex symbol became problematic in this period. It seemed that the supposed hippie ideal of sexual liberation was, when performed by Mitchell, met by curiosity and distrust. The discomfort felt by others toward her sex life in these years culminated in a series of brief articles and comments 
in Rolling Stone in the early 1970s which dubbed her the "Queen of el-Lay." The worst blow came when Rolling Stone, a magazine trusted by many to be the voice of the counterculture, published a list of her (supposed) lovers. ${ }^{67}$ She responded by refusing the magazine an interview for almost ten years. As O'Brien has acidly pointed out, "it would of course have been unthinkable for Rolling Stone to compile a similar compendium highlighting the romantic escapades of Mitchell's contemporaries like Bob Dylan." ${ }^{68}$

But, as an artist in the public eye, Mitchell invited such attention (however unintentionally, unhappily) through her confessional poetry. Her lyrics, as they shifted toward a more obvious emphasis on self-referential verse, focused repeatedly upon her love affairs and break-ups. Moreover, she tempted the curious listener by employing code that was none-too-sophisticated when making reference to (often famous) lovers and friends in her songs ("Willy" for Graham Nash is the best known example). While inviting listeners to be privy to her deepest secrets and meditations, she asked, even demanded her privacy. Mitchell's signature was no longer her exclusive property, even as she tried with ever greater tenacity to reclaim and refigure it.

In 1968, Mitchell's new record label, Reprise (a division of Warner Brothers), took stock of her appeal as a kind of sex symbol. Her apparent licentiousness with regard to sexual encounters became the focus of the label's marketing campaign for both Mitchell's second and third albums. For Clouds (1969), three rather stark adverts, consisting in a sentence or two on an otherwise blank page, were published in Rolling Stone and elsewhere. Each one led the reader toward an inevitable conclusion. The first laid out the situation plainly: "Joni Mitchell is $90 \%$ virgin." The implication being that she is the Madonna, she is the whore, and, apparently, in these proportions. Still, the ratio favoured the Madonna side, so never fear - her innocence may still be intact, her girlishness largely untrammeled.

The other two adverts in the series were somewhat more cryptic, but equally devastating. The first reads simply: "Joni Mitchell Takes Forever." Ostensibly a lamentation over the length of time Mitchell was taking to record her follow-up to Song to a Seagull, the sexual innuendo here is rather more clearly the point. Mitchell is a difficult woman to please. She takes forever to seduce, or, possibly, to bring to orgasm. If there is any doubt about this interpretation, consider the final incarnation of this advert, published as part of a full-page ad announcing the release of Clouds, which read: "Joni Mitchell Finally Comes Across." Through the language of sexual conquest, the reader is enticed to buy the album that was won, coaxed out of the girl who has finally relented to record company (read: male) advances. The advert continued, "After lo these 14 months - it has happened. On our part, it's taken blood, sweat, tears and greed. Coaxing and cajoling. Even - yes - chicanery." ${ }^{\prime 69}$ The underlying assumption here is that Mitchell was always going to "come 


\section{$96 \quad$ Henderson}

across"; it was only a matter of time. The language is deeply condescending, and Mitchell found herself largely unable to stop it. "That's what happens," she concluded recently, "when you don't show your tits."70

For Ladies of the Canyon (1970), Reprise changed tactics somewhat in its marketing scheme. This time, rather than appealing to male sexual fantasy, the obvious target of its campaign was women. The full-page advertisement which appeared in Rolling Stone assumed the form of a short story. In it, we find "Amy Foster, twenty-three years old and quietly beautiful" sitting around, moping over her recent break-up and trying "with the usual lack of success to avoid lapsing into that state of bored listlessness she'd found herself in so frequently of late." She is interrupted from this unfortunate situation by a delivery boy bearing groceries and a little marijuana joint which they light up and share. "'Mellow,' she responded, her spirits lifting slightly." The delivery boy soon asks if Amy has heard Joni Mitchell's brand new record, and brings it in to play for her:

By the time "For Free" was over they were both quite mellow indeed. As much as they downed her by reminding her all too vividly of her now-irrevocably-consummated relationship with David, "Willy" and "Conversation" were somehow reassuring - there was someone else, even another canyon lady, who really knew. Amy began to feel a little better. By the time "Circle Game" had finished, Amy was no longer dejectedly contemplating splitting for Oregon. In fact, she could scarcely wait for the sun to get through setting so she could drive up to the top of Lookout and watch Los Angeles twinkle beneath the indigo April sky. ${ }^{71}$

Saved, as it were, through the cathartic power of Mitchell's music, her lyrics, her presence, Amy is rejuvenated, energized, cured of her overarching melancholy. It is through her identification with Mitchell as another "canyon lady" that Amy begins to feel better. She finds a sense of stability through this identification - someone else feels this pain too, can articulate it, can even explain it to her. Mitchell is here allowed great power over others - she is teacher and sage to discouraged young women everywhere. But she is never demonstrated to have held any sway over the delivery boy. He fades into the background, having turned Amy on to the power of the record. He can be read two ways: on the one hand, he is simply a messenger, the catalyst to Amy's communion with Mitchell through her music. But on the other hand, since the whole scene could be read as a calculated and deliberate sexual advance, he could be seen as both shrewd and powerful. He has become aware of Amy's vulnerability, loosened her tension with the marijuana, and played to her sadness by introducing her to Mitchell's record. His role in the story remains unresolved - we do not know what happens next. 


\section{A Song for Blue, an Empty Spotlight, 1971-72}

The advent of her fame and a mounting anxiety around performing in front of vast audiences began to affect Mitchell's songwriting.72 In 1970, she left California and her live-in lover Graham Nash for Europe, where she explored the various hippie ex-patriot communities in Greece and elsewhere, before returning to America armed with fresh perspective and an album's worth of bold new material. Blue (1971) is widely hailed as Mitchell's masterwork. Startlingly confessional and at times cruelly honest, Blue seemed to plumb the depths of Mitchell's psyche. Lost love, lost confidence, a lost child, the album is about the loss of stability, of the things which kept Mitchell focused. The album begins with an admission of disconnectedness: "I am on a lonely road, and I am traveling, traveling, traveling / Looking for something what can it be?"73 The titular image "blue" recurs throughout the record, slipping into the lyric in different forms. Sometimes a lover, a pain, a loss, a state of mind, or merely a colour, "blue" becomes the support for Mitchell, in the absence of stable ground.

With Blue, music periodical Stereo Review declared that Mitchell had finally brought her emotions under control: "It is this balanced dispassion which makes her work truly womanly rather than merely girlish." ${ }^{.74}$ The New York Times agreed that the record was infused with "a womanly melancholy that is new to Miss Mitchell." 75 This "womanly melancholy" was connected to an apparent vulnerability - yet it was a private vulnerability which, paradoxically, was portrayed in a public way. As Timothy Crouse explained, "Joni Mitchell's singing, her songwriting, her whole presence give off a feeling of vulnerability that one seldom encounters even in the most arty reaches of the music business." $" 76$

This was different. A huge critical and commercial success, Blue served to cement many impressions of Mitchell's creative intentions - she was a confessor of pain, a ruminator about life and love, a romantic poet with a sad helpless brilliance. Crouse pointed to the title cut to suggest the theme of the record, "'Blue,' more than any of the other songs, shows Joni to be twice vulnerable; not only is she in pain as a private person, but her calling as an artist commands her to express her despair musically and reveal it to an audience of record-buyers." "77

With her next record, 1972's For the Roses, largely composed in near-hermetic seclusion in coastal British Columbia the following year, these impressions were further entrenched. Another generally sad, searching collection of lyrics, For the Roses lacks some of the emotional rawness of its predecessor, but carries a new heaviness in its focus on the frustrations of public life. Including dark, mysterious evocations of heroin addiction ("Cold Blue Steel and Sweet Fire") and acid-tongued denouncements of the unfair distribution of 
wealth in the music industry ("Banquet"), the record is reflective of Mitchell's self-imposed exile from the California scene. Perched alone atop a high, treelined hilltop, overlooking a placid waterway, Mitchell appears on the cover of the record as far removed as one could be from the complexity of the music industry, or the trappings of celebrity. Yet, on the title track, Mitchell paints a stark portrait of the divide between her public career and her private life; her ambivalence is so expansive it spills across both sides of the record:

I heard it in the wind last night, it sounded like applause.

Chilly now, end of summer - no more shiny hot nights;

It was just the arbutus rustling, and the bumping of the logs,

And the moon swept down on black water

like an empty spotlight. ${ }^{78}$

The paradoxical inclusion of a deliberate attempt to court the pop charts (wry and ironic though the tune may be), "You Turn Me On (I'm a Radio)" lightens the mood considerably on the second side of the record. ${ }^{79}$

For the Roses was the last album to seem to exhibit Joni Mitchell as a folksinger. Of course, this distinction remains very difficult to match to For the Roses, with its conspicuous, if abortive, forays into jazz, rock ' $n$ ' roll, and the avant-garde. ${ }^{80}$ The album was by far her most sonically adventurous to date, and, with the exception of "You Turn Me On," by no means easily accessible. But it did fit, however uneasily, into the myth of Joni Mitchell as the vulnerable girl, the poet of lost love, the Nordic songbird. Notwithstanding the series of startlingly astute and forthright discussions of heroin addiction (presumably friends and lovers James Taylor's or Eric Andersen's, not hers), empty sex with groupies and strangers (again, theirs, not hers), and the perils of an inequitable music industry, it was still, after all, a collection of acoustic songs sung by a woman, played with spare accompaniment, largely about love and pain.

All of this would change with Court and Spark (1974).

\section{One of the Boys, 1973-4}

"The one reality, however, which separates [Mitchell] from the vast majority of the rock culture stars," argued Cue Magazine in 1970, "is the fact that she is a woman. For all its revolutionary nature, real and postured, rock culture has one point in common with the most conservative establishment. Rock is the most flamboyant expression of male chauvinism." ${ }^{\prime 81}$ It is a truism that rock ' $\mathrm{n}$ ' roll is a male domain - feminist treatments of rock ' $n$ ' roll music tend to lean heavily on the construction of the essential rock ' $n$ ' roller as male, and the inevitable exclusion of women that this implies. "Women as a gender are not integrated into society," argues Gillian Gaar, "but are still seen as an 'other' that deviates from a male norm." The result, when this formula is applied to the music industry, is that "women in rock are ... defined in that order — as women first, and 
rock performers second." ${ }^{\text {82 }}$ It has rarely seemed possible to be both at once. Chrissie Hynde, longtime rock ' $n$ ' roll musician, songwriter, and devoted fan of Mitchell's music, explained in stark terms the effect this hegemonic construction of the rock ' $n$ ' roll male had on her outlook: "I never liked tits" she admitted, "because they didn't look cool with the guitar."

Malka Marom, musician, author and longtime observer of Mitchell's work, observed in 1973 that while prior to Court and Spark "[Mitchell's] image was 'the vulnerable blonde[,]' when she went with a band there was something masculine about it. There was a certain power and confidence that was conveyed through the bass and the drums. ${ }^{184}$ Mitchell, for her part, told Malka that she wasn't concerned about this apparent sea-change in her public image: "Well, I don't wanna be vulnerable anymore!" $\$$ s5 For Mitchell, and for a large faction of her critics, fans, and observers, vulnerability seemed to go hand in hand with performing alone. But, as Malka suggests, this vulnerability was deeply gendered. The female artist, performing acoustic music which was persistently labelled folk, simply was not threatening. Mitchell could still be called girlish, or, later, womanish, but rarely could she be powerful. Rather, she was vulnerable - her performances had become associated with pain, with loss, with heartbreak. This isolation was like a demonstration of her status as a woman in the industry. In the absence of female peers, Mitchell began to measure herself more readily against the yardstick of men in the industry. ${ }^{86}$ As a woman, she was isolated and "othered," but as a man she could claim to be part of the show.

In 1973, following one too many reviews labelling her as the vulnerable girl/woman poetess, Mitchell hired a progressive jazz-rock band. Graham Nash explains: "Joni has always wanted to be part of the gang. As feminine as she is, she's always wanted to be one of the boys. And when she played with the LA Express, she probably just created her own little gang." ${ }^{\prime 7}$ Mitchell has echoed this sentiment herself: "I was always one of the boys ... but I didn't lose my femininity." ${ }^{\prime 88}$

But what was femininity to Mitchell? How was it gauged, performed, its territory staked out? It should be noted that it was not only her music which underwent a transformation in this period, but her physical appearance as well. Perhaps in an effort to move beyond the old preoccupation with her straight, long blonde hair and the girlish innocence this was repeatedly taken to imply, Mitchell emerged on tour with the LA Express with a perm. She began to wear more makeup, and tended toward long, flowing evening gowns and knee-high boots. Her overall appearance began to approach that of a fashion maven of the upper-crust. This new Mitchell stood in stark contrast to her former hippie simplicity of jeans, sandals, flowered prints, and smocks. If she was afraid that by being "one of the boys," she would lose her femininity, perhaps this was a means of projecting a new exaggerated construction of feminine beauty. Alternatively, since this new image certainly moved her out of the realm of the 
innocent girl, her critics were now, more than ever, moved to describe her appearance in terms of a hyper-womanness. Either way, Mitchell's statement suggested both an awareness of the apparent maleness of the rock ' $n$ ' roll band and a preoccupation with retaining some semblance of her former feminine image as folk singer.

Court and Spark (1974) and the live Miles of Aisles (1974) both employed the accompaniment of the LA Express, Tom Scott's venerable genre-hopping outfit. The LA Express, whose own sound was none-too-easily categorized, served as a perfect fit for Mitchell as she began to explore more upbeat and expansive orchestration. ${ }^{89}$ Court and Spark remains today a bright, engaging, and enigmatic record, both for its unique musical style and its often brilliant lyrics. This was a calm, even measured form of jazz-rock - no note out of place, no imprecision creeping into the music. Any trace of vulnerability in the lyric is diffused by the utter confidence and control exhibited in the performance. As Mitchell explained to Malka in 1973, "I shouldn't be stereotyped as a magic princess as I got earlier in my career - you know the sort of twinkle twinkle little star kind of attitude - you know I didn't like that feeling. And I think the band will only show that there's another side to the music. I think it's a good expansion. ${ }^{990}$ Mitchell's continued use of new and unlikely guitar tunings and chord progressions found new legs in the widened, more complicated soundscape created by her band. On the title track, the hits "Free Man in Paris" and "Help Me," and the raucous "Raised on Robbery" (which featured a dynamic Robbie Robertson guitar solo), Mitchell seemed to have reinvented herself yet again. Both the lyrics and vocal performances reflected the confidence and swagger of a veteran, while the music pushed hard at the boundaries of contemporary rock ' $n$ ' roll, jazz, and pop music formulas.

Contemporary critic John T. Hall agreed: "she wears the rock idiom well, using it to her own purposes. There is never a hint that it may overpower her, she drives it like a sports car." ${ }^{\prime 91}$ The language here is all about power and control - exploring Mitchell's expected role as the vulnerable girl was no longer useful.

During the Court and Spark period (1973-4), Mitchell's observers became concerned about reconciling the maleness of her rock ' $n$ ' roll persona with her feminine beauty. One way some observers overcame this problem of categorization was to invent a symbolic, impossible role for Mitchell to embody. The image of a fantastic, otherworldly being, a conflation of the Madonna/whore dichotomy with the mystic poetess, serves as a means of transcending the very worldly concern of fitting Mitchell into an expected category. Descriptions of Mitchell's ethereal qualities, largely the product of the male imagination, were ever-present in the period. Folksinger and longtime friend Eric Andersen recalls: "I think people have this image and idea of this fragile Nordic goddess who's descending from the mountains with, like, wisps of Wagner and Tiffany 
windchimes behind her." ${ }^{.92}$ Such surreal characterizations provided a means of speaking of Mitchell as somehow both woman (beautiful/fragile) and man (powerful) and neither at the same time.

They further sidestep the issue of maleness by infusing her with a superhuman quality which retains fragility and femininity, but redirects the powerful maleness of her artistry into an erotic hyper-womanness. A Time Magazine cover story in December 1974, described her as "the rural neophyte waiting in the subway, a free spirit drinking Greek wine in the moonlight, an organic Earth Mother dispensing fresh bread and herb tea, and the reticent feminist who by trial and error has charted the male as well as the female ego." ${ }^{\prime 93}$ Earlier that year, an article in Melody Maker had taken an even more exaggerated view, "Joni Mitchell is disturbing in a very real way because after watching and listening to her for a while you start thinking she's not just a woman, she's WOMAN, embodying all male desires and expectations." The author, Michael Watts, went on to romanticize Mitchell's power as "WOMAN" even further: "Small wonder then that a legion of very well-known men have been sufficiently drawn by the siren's call to jump in headfirst after her. So this is the meaning of worship? Like the White Goddess of mythology she beckons, elusive, virginal and not a little awe-inspiring. It must be a trifle terrifying to know you appear that perfect." ${ }^{\text {94 }}$

\section{A Conclusion: Holding Sand}

In 1979, Cameron Crowe asked Mitchell if she had "many close women friends":

I have a few good women friends. I like them and I trust them. But generally speaking, I'm a little afraid of women. I don't know, it's a funny time for women. We demand a certain sensitivity.... I think we ask men to be sensitive and equal but deep down think it's unnatural. And we really want them to be stronger than us.... I believe in equality. I believe that I am male and I am female. Not that I'm saying I'm bisexual - I believe in heterosexuality. I think ultimately it's the most difficult and nourishing of them all. But I do understand homosexuality in these times. It seems to be a peculiar, in many cases, necessary alternative to this mess that's happening between the men and the women. ${ }^{95}$

Mitchell's oscillation between categorical essentialism and an outright refusal of biological determinism is striking, but it can be taken as a certain summation of the themes discussed above. In her construction, there is some essential meaning ascribed to the categories "woman," "man," and "homosexual," yet it is up to the individual to choose where s/he fits. In her assessment, men are 
expected to be stronger, and women more sensitive. The "mess" to which she refers seems to have arisen out of a preoccupation with pushing men into a more feminine, sensitive role. Homosexuality is seen as an escape - it allows the individual to avoid the whole issue of male/female role-playing. Yet Mitchell, in claiming to believe that she is both "man" and "woman," simultaneously endorses the essential validity of the categories while subverting their inescapability. She accepts that she has occupied both roles, sometimes concurrently, in the eyes of her peers, her critics, her fans, and observers. Yet she is quick to remind us that she has never fully transcended these roles - neither has she escaped them, nor has she adopted one over the other. She is either man or woman, sometimes both, never neither. Her joking claim to Alice Echols that she has "the soul of a Martian" seems, then, a rare instance where Mitchell has avoided facing the complexities of her signature and her gender performances.

This article has considered some of the meanings the signature "Joni Mitchell" conveyed in the first nine years of her career. In an effort to expose the instability (or inconsistencies) of such meanings, this article has examined constructions in the popular press of "Joni Mitchell" as "girl," as "woman," and as "goddess," and the attempts to develop her image as "sex symbol" and "feminine sage" by her record company. It has also considered Mitchell's own, deeply ambiguous comments about her shifting identity constructions, and attempted to reconcile them to the hegemonic constructions of expected gender roles in the music industry.

Joni Mitchell has many, and one, signature. She is a performer; an artist who seems to express her private identity in a public way. Her signature is performed privately, through her music, her art, but it is also imposed upon her from outside through public interpretation and expectation. Mitchell's performance as "woman" is thus both private and public, both in and out of her control. The hegemonic construction of "female folksinger" became for Mitchell a kind of symbolic prison - it demanded of her that she be clearly defined, obvious, and therefore, immutable. But the persistent challenge she posed to this hegemony was expressed through her refusal to allow herself to become categorized - her mutability was always already the meaning of her signature. Both embodying and tirelessly shifting the "signifier" behind the signature, Mitchell frequently manipulated and eluded the figurative prison of hegemonic expectation. The "Joni Mitchell" that was expected, that was constructed by the public and critical response to her performances, never was the same "Joni Mitchell" that wrote the songs. The critical public expected stability, but what it got was ambiguity and originality.

For her part, Mitchell never could resolve this apparent opposition of stability and artistry. While in Greece in 1970, Mitchell wrote about the quandary to her lover Graham Nash. "It was," he remembers, "her way of saying 'goodbye' to me." 
"If you hold sand too tightly in your hand" Mitchell explained, "it will slip through your fingers." ${ }^{.96}$

The author wishes to express his thanks to Karen Dubinsky for her indispensable advice and kind support during the writing of this article. Thanks to Karen Pegley, Cheryl DesRoches, Rose Wagner, and Robin Grazley for reading an early draft and offering helpful suggestions and criticisms. Thanks also to Alice Echols, whose work both inspired and informed this article.

\section{Notes}

1 "Joni Mitchell — Interviewed by Cameron Crowe," in The Rolling Stone Interviews, 1967-1980, ed. The Editors of Rolling Stone (New York: St-Martin's Press, 1981), 378. ${ }^{2}$ Mitchell had exactly two producers in this period - David Crosby (whom she claimed had only "pretended" to produce her debut) and herself. She also refused a manager until late in 1967, something that was utterly unheard of.

3 "They don't put Dylan with Men of Rock; why do they do that to me with women?" Joni Mitchell quoted in Karen O'Brien, Shadows and Light: Joni Mitchell, The Definitive Biography (London: Virgin Books, 2001), 4.

${ }^{4}$ Ibid., 212.

${ }^{5}$ Gillian Gaar, She 's a Rebel: The History of Women in Rock and Roll (Seattle: Seal Press, 1992); Ellen Schwartz, Born a Woman: Seven Canadian Women Singer-Songwriters (Winlaw: Polestar Press, 1988). See also Sheila Whiteley, Women and Popular Music: Sexuality, Identity and Subjectivity (New York: Routledge, 2000).

${ }^{6}$ Madonna is the most notable exception. See Alice Echols, Scars of Sweet Paradise: The Life and Times of Janis Joplin (New York: Henry Holt, 2000); Victor Bockris and Roberta Bayley, Patti Smith: An Unauthorized Biography (New York: Simon and Schuster, 1999). See also Lori Burns and Melisse Lafrance, Disruptive Divas: Feminism, Identity and Popular Music (London: Taylor and Francis, 2001) for a lengthy elaboration on this persistent problem.

' O'Brien, Shadows and Light; Brian Hinton, Joni Mitchell: Both Sides Now, the Biography (London: Sanctuary, 2000).

${ }^{8}$ Douglas Fetherling, Some Day Soon: Essays on Canadian Songwriters (Kingston: Quarry Press, 1991); Marco Adria, Music of Our Times: Eight Canadian SingerSongwriters (Toronto: Lorimer Press, 1990).

'Alice Echols, “The Soul of a Martian': A Conversation with Joni Mitchell," Shaky Ground: The Sixties and Its Aftershocks (New York: Columbia University Press, 2002). Odd because Echols seems to legitimate Mitchell's joking claim to transcend gender, race, and class. This seems a rare lapse in theoretical concern from Echols.

${ }^{10}$ Hence Echols' emphasis on Mitchell's (facetious) attempt to escape such complexity: "I have the soul of a ... Martian!"

${ }^{11}$ See David Brackett, "(In Search of) Musical Meaning: Genres, Categories and 
Crossover," in Popular Music Studies, ed. David Hesmondhalgh (London: Arnold Publishers, 2002), 65-84 for a good introduction to debates surrounding meaning and classification in popular music.

${ }^{12}$ Power in the music industry is exercised through a mutable relationship between consent and coercion of artistic freedom. The confines of this paper do not permit me to engage this topic fully, but I shall attempt to provide some brief description of this process. The basic structure looks something like this: the artist retains some power (as public performer, writer, artist), while the industry, usually as represented by the record label which, in a legal sense, "owns" the artist, often retains more. The consumer, insomuch as she can buy or not buy any product, retains a certain degree of power - if she refuses the product, then both artist and industry are at her mercy, for the moment. But, as Richard Middleton has argued: "We [as consumers] do not choose our music tastes freely; nor do they reflect our 'experience' in any simple way. The involvement of subjects in particular musical pleasures has to be constructed.... Subjects themselves [...] have a role to play (of recognition, assent, refusal, comparison, modification); but it is an articulatory, not a simplistically creative or responsive role." The power relations exhibited here are anything but static and deterministic — however, this general pattern of power distribution allows us to see the way that artistry can largely be relegated to the status of commodity, codified, and categorized so as to be exploited, marketed, consumed. Richard Middleton, Studying Popular Music (Milton Keynes: Open University Press, 1990), 62.

${ }^{13}$ Judith Butler, Gender Trouble: Feminism and the Subversion of Identity (London: Routledge, 1990), 25. See also her elaboration on these themes in Bodies That Matter (New York: Routledge, 1993).

${ }^{14}$ Thus, as Joan Scott concludes, "It is not individuals who have experience, but subjects who are constituted through experience." Joan W. Scott, "The Evidence of Experience," Critical Inquiry 17 (Summer 1991): 773-797, 779.

${ }^{15}$ In this way, I am following on an argument put forward by Shelia Whiteley in her introduction to Sexing the Groove: Popular Music and Gender (London: Routledge, 1997). She explains that her collection "is concerned with the ways in which the production of meaning is mediated by the social practice of popular music and how this informs gendered identity" (xvii). I am interested in much the same thing, but, using Joni Mitchell as a subject, seek to develop a more detailed theoretical framework.

${ }^{16}$ See Jacques Derrida, The Ear of the Other: Otobiography, Transference, Translation, trans. Peggy Kamuf et al. (New York: Schocken, 1985).

${ }^{17}$ Stephen Scobie, Alias: Bob Dylan (Red Deer: Red Deer Press, 1994). For an invaluable treatment of these concerns with regard to Dylan's work, see pages 47-49.

${ }^{18}$ O'Brien, Shadows and Light, 15.

19 Malka, "Face to Face," Macleans, June 1974.

${ }^{20}$ It can be said that Mitchell was, in this way, also relating her adulthood to the onset of some illness. The loss of innocence, a theme to which Mitchell alludes in a number of her early compositions ("The Circle Game," "Both Sides Now") is frequently conflated 
with a kind of (painful) achievement of clarity.

${ }^{21}$ Quoted in O'Brien, Shadows and Light, 26.

${ }^{22}$ Rolling Stone Interviews, 381.

${ }^{23}$ Ibid., 381.

${ }^{24}$ Quoted in O'Brien, Shadows and Light, 28.

${ }^{25}$ Dylan claims that, in October 1959, "he walked into a Minneapolis coffeehouse ... and asked for a job as a folksinger. The owner asked his name, and he answered, off the top of his head, 'Bob Dylan."' Scobie, Alias, 47.

${ }^{26}$ Quoted in O'Brien, Shadows and Light, 32.

${ }^{27}$ Ibid., 32.

${ }^{28}$ Popularized in a "how-to" recording by Pete Seeger who based his style of guitar picking on that of his black housemaid, herself a songwriter, Elizabeth "Libba" Cotten.

${ }^{29}$ Her guitar technician and longtime friend Joel Bernstein estimates that "she has originated at least 35 unique tunings," O'Brien, Shadows and Light, 196.

${ }^{30}$ Quoted in Ibid., 35.

${ }^{31}$ See Nicholas Jennings, Before the Gold Rush (Toronto: Penguin Canada, 1997), 7980 .

${ }^{32}$ Musician Ani DiFranco, after interviewing Mitchell in 1998, argued that it was not the prospect of motherhood and poverty, but rather the irreconcilables of career and motherhood which forced her decision. Mitchell responded (through her management) with the outright refusal of this interpretation. See "Ani DiFranco chats with Iconic Joni Mitchell," Los Angeles Times, 20 September 1998, and Los Angeles Times, 17 January 1999.

${ }^{33}$ Mitchell, The Complete Poems and Lyrics, 69.

${ }^{34}$ The Chuck and Joni show is described as "a variety act, with him performing very theatrical, 'Brechtian' shtick and Joni doing her own folky thing. When they did team up on duets, the songs they sang were often [Gordon] Lightfoot's." Jennings, Gold Rush, 84 .

${ }_{35}$ "Two Single Acts Survive a Marriage," Detroit News, 6 February 1966.

${ }^{36}$ Reproduced in "Woman of Heart and Mind," CBC Life and Times, dir. Susan Lacy, original air date: 4 and 11 March (in two parts), 2003.

${ }^{37}$ See Gaar, She's $A$ Rebel for a book-length discussion of this very point.

${ }^{38}$ Ibid., xiii.

${ }^{39}$ See also Dickerson, Women on Top (New York: Billboard Books, 1998).

${ }^{40} \mathrm{Baez}$ is especially significant. Her early 1960 s music (largely material culled from the folk traditions of both black and white America) was generally performed without accompaniment. Further, she refused hegemonic conventions of performance style and costume, opting for a no-makeup, plain clothes look which in turn set the standard for the "authentic" look for female folk musicians. She was not a hit-maker as far as singles were concerned, but maintained consistent record sales (she recorded her first of six gold albums in 1960), making her one of the first artists to become successful without recording a hit song. See Gaar, She's A Rebel, 92. 
106 Henderson

${ }^{41}$ Echols, Scars of Sweet Paradise, xv.

${ }^{42}$ See Charlotte Grieg, Will You Still Love Me Tomorrow? Girl Groups From the Fifties On (London: Virago Books, 1989); also Gaar, She's A Rebel, 28-67.

${ }^{43}$ For a loving, well-researched account of the immense resistance met initially by Dylan and the Band as they tried to enforce their crossover from folk to rock, see Greil Marcus, Invisible Republic: Bob Dylan's Basement Tapes (New York: Henry Holt, 1997), especially pages 4-41. The folk-rock mantle was, however, rapidly taken up by million-selling artists the Byrds and the Lovin' Spoonful and by 1966 it had become a dominant genre in the industry. See James Miller, Flowers in the Dustbin (New York: Simon and Schuster, 1997) and especially Richie Unterberger, Turn! Turn! Turn! The 60s Folk Rock Revolution (San Francisco: Backbeat, 2002).

${ }^{44}$ However, this was a hotly contested terrain - Janis Joplin's struggle for fame and fortune whilst eschewing her expected role as 'woman' speaks to the myriad difficulties still faced by even the more commercially successful women in the industry. See Echols, Scars of Sweet Paradise, 191-228.

${ }^{45}$ This trend is, of course, intrinsically related to the rise of feminism and, in 1968 , women's liberation movements.

${ }^{46}$ There are numerous excellent studies of the American countercultures of the $1960 \mathrm{~s}$, and far too many to list here. But, the essential works include: Peter Braunstein and Michael William Doyle, eds., Imagine Nation: The American Counterculture of the 1960s and 70s (New York: Routledge, 2002); Echols, Shaky Ground; Todd Gitlin, The Sixties: Years of Hope, Days of Rage (Toronto: Bantam Books, 1987).

${ }^{47}$ Butler, Gender Trouble.

${ }^{48}$ Alice Echols, Daring to be Bad: Radical Feminism in America, 1967-1975 (Minneapolis: University of Minnesota Press, 1989), 15. See also Ann Snitow and Rachel DuPlessis, The Feminist Memoir Project (New York: Three Rivers Press, 1998); Ruth Rosen, The World Split Open: How the Modern Women's Movement Changed America (New York: Viking, 2000).

${ }^{49}$ Echols, Daring to Be Bad, 15.

${ }^{50}$ Debra Michals, "From Consciousness Expansion to Consciousness Raising: Feminism and the Countercultural Politics of the Self," Imagine Nation, ed. Braunstein and William Doyle, 41-68.

s1 Tom Rush and George Hamilton IV both recorded Mitchell's "Urge for Going" in 1966; Rush, Judy Collins, and Buffy Sainte-Marie all recorded "The Circle Game"; Judy Collins' take on "Both Sides Now" (1967) became an international hit.

${ }^{52}$ Mitchell spoke these words in 1996 in an illuminating interview she gave upon being awarded the Polar Music Prize in Stockholm, Sweden. See: http://www.jonimitchell.com/PolarPressConference.html.

${ }^{53}$ This is debatable. Her best and most creative period (from an artistic [and subjective: $m y$ ] point of view) is the one which immediately followed the period at issue here. From the awkwardly titled 1975 masterpiece The Hissing of Summer Lawns through the stunning, spare Hejira (1976), the searching (and spotty) Don Juan's Reckless Daughter 
(1978), and culminating in the weird, mysterious crossover experiment of Mingus (1980), the mid-to-late 1970s represents a string of truly groundbreaking material. Significantly, as she widened her musical horizons in this period, employing larger and larger ensembles, experimenting with jazz and world music, pushing her signature through a series of confounding articulations, her fanbase and critical support dwindled. Mitchell's 1980s contributions - - apart from the inevitable three or four great compositions per record - wallowed in overproduction and somewhat stilted politics. Her 90s releases (if vastly improved attempts toward harnessing a more organic sound) have continued to fall short of her 1970s output. Mitchell recently retired from public life, rather triumphantly, after releasing two re-imaginings of her early compositions (and standards by others) backed by an orchestra.

${ }^{54}$ Rather, it demonstrated a high degree of innovation and experimentation with the form. A particularly poetic attempt to articulate her unique early contributions in technique and style, "Richly modal, [her music] is pervaded by an exotic calmness, reminding one of things like wind chimes or the glass globes Japanese fisherman use to float their nets. Against this delicate background her reedy voice with its natural vibrato is free to discover its own paths of harmony.... Suddenly, like a hawk on an updraft, she will carve a breathtaking harmonic arc and soar out over the landscape of her verse." James Lichtenberg, "Joni Mitchell," Cue, 12 December 1970.

${ }^{55}$ Holly Kruse, "Abandoning the Absolute: Transcendence and Gender in Popular Music Discourse," Pop Music and the Press, ed. Steve Jones (Philadelphia: Temple University Press, 2002), 134-155. See also Brenda Johnson-Grau, "Sweet Nothings: Presentations of Women Musicians in Pop Journalism" from the same volume, 202-218.

${ }^{56}$ Very few female popular musicians, by 1969 , were songwriters in their own right. The most famous female songwriters tended to work behind the scenes (and often with a man for a partner, as with Carole King). Apart from the rare cases of Bobby Gentry (a onehit wonder in 1967), Loretta Lynn (virtually alone in the country scene), and Melanie (dogged by her image as a symbol for (female) hippie dippy immaturity), top ten hits written and performed by women were unlikely.

${ }^{57}$ Moreover, Mitchell's inventive and wholly original approach to the guitar-- especially as exemplified through the fascinating and unique open tunings she had begun to develop early in her career - provoked glowing praise from observers of her method. A recent examination of Mitchell's technique attempted to put her idiosyncratic sound into words, "At the heart of the music of Joni Mitchell is a constant sense of surprise and discovery. The melodies and harmonies rarely unfold in ways that our ears, tamed by pop-music conventions, have come to expect. Her guitar doesn't really sound like a guitar: the treble strings become a cool-jazz horn section; the bass snaps out syncopations like a snare drum; the notes ring out in clusters that simply don't come out of a normal six-string. And her voice adds another layer of invention, extending the harmonic implications of the chords and coloring the melody with plainspoken commentary as well as charged poetic imagery." Jefferey Pepper Rodgers, "My Secret Place," Acoustic Guitar, August 1996. 
${ }^{58}$ Walter Naedele, "Outside Schwenksville," Philadelphia Evening Bulletin, 24 August 1968

${ }^{59}$ Happy Traum, "Joni Mitchell," Rolling Stone, 17 May 1969.

60 "Folksongs," Variety, 21 September 1966.

61 "Rising Folksinger from Saskatoon Discusses Career," Saskatoon Star-Phoenix, 28 July 1966.

${ }^{62}$ Frank Gray, "Folk Singer's Biggest Wish," Saskatoon Star-Phoenix, 2 February 1968.

${ }^{63}$ Walter Naedele, "Outside Schwenksville," Philadelphia Evening Bulletin, 24 August 1968.

${ }^{64}$ John MacFarlane, “A Hit for Joni Mitchell, A Miss for Lightfoot," Toronto Daily Star, 20 April 1968.

65 "Woman of Heart and Mind," 4 March 2003.

66 "I thought, 'You'd better know who you're applauding up here.' It was a compulsion to be honest with my audience." Quoted in Echols, Shaky Ground, 214.

${ }^{67}$ Rolling Stone, 4 February 1971. The distinction "Old Lady of the Year" was given to Mitchell "for her friendships with David Crosby, Steve Stills, Graham Nash, Neil Young, James Taylor, et al." Adding insult to injury, "Old Man of the Year" was Charlie Manson.

${ }^{68}$ O'Brien, Shadows and Light, 8.

${ }^{69}$ Appeared in Rolling Stone, 26 July 1969.

${ }^{70}$ Quoted in Echols, Shaky Ground, 219. It must be noted that in the following year, her "tits" made an appearance in the film Celebration at Big Sur. A documentary about the music festival held at the Esalen Institute near Big Sur California, the film contained a scene wherein Mitchell and other musicians, male and female, lounged naked in a natural hot spring. If only briefly, and in a scene devoid of any overt sexual innuendo, Mitchell did allow for her body to become visible to her audience. Later, with the release of For the Roses in 1972, she posed naked, with her back to the camera, for the inlay photograph. Later still, for The Hissing of Summer Lawns (1975), the inlay shot is of Mitchell in a black string bikini, supine in a swimming pool. Again, nothing erotic seems implied, but Mitchell does appear to have a certain preoccupation with co-presentations of her signature with her body. See Fetherling, Some Day Soon, 82, for a brief discussion of Mitchell's representations of "the spectacle of her own body."

${ }^{71}$ Appeared in Rolling Stone, 14 May 1970.

72 "I felt like a cellophane wrapper on a pack of cigarettes," she later explained. Rolling Stone Interviews, 388.

73 "All I Want," Mitchell, The Complete Poems and Lyrics, 65.

${ }^{74}$ Peter Reilly, "Joni Mitchell Sings Her Blues," Stereo Review, October 1971.

${ }^{75}$ Dan Heckman, "Joni Mitchell at a Crossroads," The New York Times, 8 August 1971.

${ }^{76}$ Timothy Crouse, "Blue," Rolling Stone, 5 August 1971.

${ }^{77}$ Ibid. My emphasis.

${ }^{78}$ For the Roses, 1972. Mitchell, The Complete Poems and Lyrics, 97.

79 “Oh honey you turn me on / I'm a radio / I'm a country station / I'm a little bit corny 
/ I'm a wildwood flower / waving for you / I'm a broadcasting tower / waving for you." Mitchell, The Complete Poems and Lyrics, 101.

${ }^{80}$ Los Angeles-area musician Tom Scott added touches of all of these to the mix as a session musician on the record.

${ }^{81}$ James Lichtenberg, "Joni Mitchell," Cue, 12 December 1970.

${ }^{82}$ Gaar, She's $A$ Rebel, xi-xii.

${ }^{83}$ The Times Magazine, 24 April 1999. Quoted in O'Brien, Shadows and Light, 209. Even more to the point, perhaps, was Patti Smith's paradoxical claim in the mid-70s (at the very height of her fame as a genre-busting rock star) that rock ' $n$ ' roll was a man's job. She didn't want to see "some chick's tits banging against a guitar." Scott Cohen, "How a Little Girl Took Over a Tough Gang: The Hard-Rock Poets," Oui, July 1976. ${ }^{84}$ "Woman of Heart and Mind," 11 March 2003. This conversation took place in 1973. ${ }^{85}$ Ibid.

${ }^{86}$ By now, Laura Nyro had become a bona fide peer in the eyes of some. Another "folksinging" woman who wrote her own material, Nyro is perhaps the foil to Mitchell in this period. However, neither her career nor her body of work stands much serious comparison to Mitchell's. While Mitchell re-invented herself with great success, Nyro faded away.

${ }^{87}$ "Woman of Heart and Mind," 11 March 2003.

${ }^{88}$ Quoted in Echols, Shaky Ground, 222.

${ }^{99}$ Exploring the terrain between jazz, rock'n'roll and soul music, the LA Express was part of a new direction in pop music in the mid-1970s. Steely Dan, Pink Floyd, Little Feat, Frank Zappa, and The Grateful Dead were all, in their diverse ways, Mitchell's fellow travelers in this period, forging new ground in the spaces between what they viewed as restrictive categories of expression. Mitchell explained in an informative 1996 interview, "You have to understand, not only was it difficult to be a woman in the business at that time, but the camps of music were very isolated from one another. Jazzers and rockers and folkies did not mix, and I had moved through all of these camps. I was moving into the jazz camp. As far as the rockers were concerned, that was betrayal, and definitely to the folkies." Jefferey Pepper Rodgers, "My Secret Place," Acoustic Guitar, August 1996.

90 "Woman of Heart and Mind," 11 March 2003.

${ }^{91}$ John T. Hall, “Joni Mitchell's Albums Trace a Coming of Age," Ithaca New Times, 10

February 1974.

${ }_{92}$ "Woman of Heart and Mind," 11 March 2003.

${ }_{93}^{93}$ David De Voss, “Rock'n'Roll's Leading Lady,” Time, 16 December 1974.

${ }^{94}$ Michael Watts, “The Divine Miss M,” Melody Maker, 27 April 1974.

${ }^{95}$ Rolling Stone Interviews, 389. My emphasis.

96 "Woman of Heart and Mind," 4 March 2003. 